\title{
Correction to: Engineered nanomaterials in plant diseases: can we combat phytopathogens?
}

\author{
Graciela Dolores Avila-Quezada ${ }^{1} \cdot$ Patrycja Golinska ${ }^{2} \cdot$ Mahendra Rai $^{2,3}$
}

Published online: 11 February 2022

๑) Springer-Verlag GmbH Germany, part of Springer Nature 2022

\section{Correction to: Applied Microbiology and Biotechnology (2022) 106:117-129 https://doi.org/10.1007/s00253-021-11725-w}

In the published version, figure legend of adapted figure 3 is not correct.

The correct Figure legend is:

Fig 3. Possible mechanism of action of the capped AgNPs against $S$. sclerotiorum. a Degradation of cell wall by hydrolytic enzymes secreted by $T$. harzianum; b membrane disruption and oxidative stress caused by AgNPs; c synergistic effect of the biogenic AgNPs and the capping hydrolytic enzymes against $S$. sclerotiorum. Adapted from Guilger-Casagrande et al. (2021) under the
Creative Commons Attribution 4 International Licence and modified.

\section{Reference}

Guilger-Casagrande M, Germano-Costa T, Bilesky-José N, PasquotoStigliani T, Carvalho L, Fraceto LF, de Lima R (2021) Influence of the capping of biogenic silver nanoparticles on their toxicity and mechanism of action towards Sclerotinia sclerotiorum. J Nanobiotechnol 19(1):53. https://doi.org/10.1186/s12951-021-00797-5

Publisher's note Springer Nature remains neutral with regard to jurisdictional claims in published maps and institutional affiliations.

The online version of the original article can be found at https:// doi.org/10.1007/s00253-021-11725-w

\section{Mahendra Rai}

mahendrarai@sgbau.ac.in

1 Facultad de Ciencias Agrotecnológicas, Universidad Autónoma de Chihuahua, Escorza 900, Chihuahua 31000, México

2 Department of Microbiology, Nicolaus Copernicus University, 87-100 Toruń, Poland

3 Nanotechnology Laboratory, Department of Biotechnology, SGB Amravati University, Amravati, Maharashtra 444 602, India 